\title{
Do Scale Frames Matter? Scale Frame Mismatches in the Decision Making Process of a "Mega Farm" in a Small Dutch Village
}

\author{
Maartje van Lieshout $^{1}$, Art Dewulf $^{2}$, Noelle Aarts $^{3,4}$, and $\underline{\text { Catrien Termeer }}^{5}$
}

\begin{abstract}
Scale issues are an increasingly important feature of complex sustainability issues, but they are mostly taken for granted in policy processes. However, the scale at which a problem is defined as well as the scale at which it should be solved are potentially contentious issues. The framing of a problem as a local, regional, or global problem is not without consequences and influences processes of inclusion and exclusion. Little is known about the ways actors frame scales and the effect of different scale frames on decision making processes. This paper addresses the questions that different scale frames actors use and what the implications of scale frames are for policy processes. It does so by analyzing the scale frames deployed by different actors on the establishment of a so-called new mixed company or mega farm and the related decision making process in a Dutch municipality. We find that actors deploy different and conflicting scale frames, leading to scale frame mismatches. We conclude that scale frame mismatches play an important role in the stagnation of the decision making process.
\end{abstract}

Key Words: decision making; frames; framing; levels; mega farm; policy process; scale mismatch; scales

\section{INTRODUCTION}

Complex policy processes increasingly play out in multilevel and multiscale contexts; this means that actors and processes operating on different scales and levels are involved. Among others, administrative, spatial, and time scales can be distinguished, whose levels and boundaries do not neatly correspond with each other. This makes it difficult to pinpoint who is responsible for what, who directs the process, and how problems and solutions are defined and valued (e.g., Lovell et al. 2002, Lebel et al. 2005).

Scales can be defined as "the spatial, temporal, quantitative, or analytical dimensions used to measure and study any phenomenon" (Gibson et al. 2000:218). Apart from scales, levels can be distinguished. Levels are "the units of analysis that are located at the same position on a scale" (Gibson et al. 2000:218), or in other words, the different locations on a scale. On the administrative scale, for example, we can distinguish the global, European, national, provincial, and municipal levels, and on the time scale we can distinguish between, e.g., short-term and long-term processes (Cash et al. 2006). Scales, however, are not just out there as fixed entities with an unequivocal meaning. Through the process of framing, actors highlight different aspects of a situation as relevant, problematic, or urgent, and by doing so situate issues on different levels and scales. Framing refers to the interpretation process through which people construct and express how they make sense of the world around them (Gray 2003). Resilience to flooding, for example, could be framed as a national issue of dike infrastructure, or as a local issue of flood-proof housing. We use the term "scale framing," by which we mean the process of framing an issue using a certain scale and/or level. Scale framing is not without consequences. It makes a difference in terms of actors, interests, and interdependencies whether problems are addressed at one scale level or another (Dewulf et al. 2011). Scale framing can be used as a means of legitimizing inclusion and exclusion of actors and arguments in policy processes (Kurtz 2003). Actors can behave strategically by scaling the problem such that they

\footnotetext{
${ }^{1} \mathrm{PhD}$ candidate Public Administration and Policy Group, Wageningen University, ${ }^{2}$ Assistant professor Public Administration and Policy Group Wageningen University, ${ }^{3}$ Associate professor Communication Science Group Wageningen University, ${ }^{4}$ Professor Strategic Communication University of Amsterdam, ${ }^{5}$ Professor of Public Administration and Policy Wageningen University
} 
situate themselves at the center of power (Termeer and Kessener 2007). Obviously these processes are highly contested as actors attempt to reshape power and responsibilities (Kurtz 2003).

Although different authors address scale issues in the context of natural resource management (e.g., Lovell et al. 2002, Adger et al. 2005, Berkes 2006, Borgström et al. 2006, Young 2006, Biggs et al. 2007, Folke et al. 2007, Olsson et al. 2007, Papaik et al. 2008), only a few study scales as social constructions (e.g., Delaney and Leitner 1997, Lebel et al. 2005). In some disciplines, for example, political and human geography, the construction of scales has been studied, but only a few address the use of scale frames in policy processes (e.g., Kurtz 2003, Harrison 2006, Dewulf et al. 2011).

In this paper, we study scales as social constructions, focusing on the role of scale frames in a complex decision making process on sustainability issues. We address two related research questions: (1) Which scale frames do actors use and how do these differ from each other?; (2) What are the implications of scale frames for policy processes, with regard to inclusion and exclusion of actors and arguments?

We address these questions through an in-depth case study of the decision making process in the establishment of a so-called mega farm in a designated agricultural development area (ADA) near a small Dutch village. The fact that different actors refer to the same farm as a new mixed company (NMC), a mega farm, a pig flat, or an agricultural production park indicates that the development is contentious and gives rise to divergent frames. All these different names have different connotations and frame the farm in different ways. In this paper, we show how different actors construct and use different scale frames with regards to the farm, and we discuss their implications. In the following, we build the theoretical framework we need for the analysis, explicate the methods used, present the results, and discuss their implications.

\section{THEORETICAL FRAMEWORK}

Because we are interested in scale frames and their implications for policy making, we developed a theoretical framework starting from the concepts of policy making, frames and framing, scales and scale framing. We used theories from different scientific disciplines, including policy science, public administration, communication science, organizational psychology, and human and political geography.

\section{Policy making}

We followed authors like Stone (1988), Fischer and Forester (1993), and Hajer and Wagenaar (2003) in their idea that public policy is largely made up of language. As Fischer and Forester (1993:2) make clear: "Policy analysis and planning are practical processes of argumentation." Deborah Stone explains that the essence of policy making is the struggle over ideas: "Policy making is a constant struggle over the criteria for classification, the boundaries of categories and the definition of ideas that guide the way people behave" (1988:11). Policy making is reasoning by metaphor and analogy; it is trying to get others to see the situation as one thing rather than another (Stone 1988). In other words, "policymaking is mostly a matter of persuasion" (Goodin et al. 2006:5).

From this point of view, problems, causes, and solutions are not given, but "created in the minds of citizens by other citizens, leaders, organizations, and government agencies, as an essential part of political maneuvering. Symbols, stories, metaphors, and labels are all weapons in the armamentarium" (Stone 1988:156). The fact that problems, causes, and solutions are created by individuals and groups in society leads to a multiplicity of perspectives on the problem, its causes, and possible solutions. According to Rein and Schön (1996), this multiplicity in the policy realm is reason for worry. They suggest a frame-reflective approach to deal with it.

In line with this, we view the decision making process under study as part of a larger policy process (see Appendix 1), that is, as a series of on-going discursive negotiations (see also Aarts and van Woerkum 2002). This means that we discuss the impact of scale frames on ongoing negotiations, not on succeeding stages in a policy process.

\section{Frames and framing}

We used theories on frames and framing (Bateson 1972, Goffman 1974, Schön and Rein 1994, Lewicki et al. 2003, Aarts and van Woerkum 2006, 
Dewulf et al. 2009) to obtain a better understanding of how actors use scale frames to make sense of contentious issues. Frame analysis starts from the idea that people make sense of situations for themselves and for others by means of certain perspectives or frames that they deploy in interaction (Weick 1995, Kurtz 2003, Harrison 2006, van Lieshout and Aarts 2008, Dewulf et al. 2009). As Entman (1993:52) puts it, "to frame is to select some aspects of a perceived reality and make them more salient in a communicating context, in such a way as to promote a particular problem definition, causal interpretation, moral evaluation, and/or treatment recommendation for the item described." Consequently, the framing of an issue, including scale framing, is the result of processes of interaction and negotiations between different actors, and at the same time it is the input for these processes. A policy process consists of a series of framings of the issues under debate.

\section{Scales}

The concept of scale is applied in different scientific disciplines that attribute different meanings to it. Different scale dimensions can be distinguished; for example, spatial, temporal, or administrative scales. Furthermore, the concepts of scale, level, hierarchy, etc., are used as synonyms in certain disciplines whereas they are strictly separated in others. Gibson et al. (2000) and Buizer et al. (2011) present an overview of how scales are conceptualized in various disciplines.

We drew on the literature on politics of scale in human and political geography to discuss the use of scales as sense-making devices. This approach defines scale as a social construct, "suggesting that scale is not pre-given but a way of framing conceptions of political-spatiality" (Kurtz 2003:894, see also Delaney and Leitner 1997, Marston 2000, Brenner 2001, Harrison 2006). A problem may, temporarily, be formulated in such a way that certain scales become dominant whereas others are attributed less significance. "Central to the politics of scale is the manipulation of power and authority by actors and institutions operating and situating themselves at different [spatial] scales. This process is highly contested, involving numerous negotiations and struggles between different actors as they attempt to reshape [the spatiality of] power and authority" (Leitner 2004:238-239, author's brackets, Dewulf et al. 2009). To put it differently, the setting of a scale depends on the actors involved and the goals they pursue, and vice versa. It is a causal circular process in which social, institutional, structures influence problem definitions and problem definitions influence social structures (Termeer and Kessener 2007, Dewulf et al. 2011).

\section{Scale frames}

In this paper, we focus on the scale frames that different actors construct to understand the role of these frames in the sense-making of an issue in policy processes. Scale frames can be considered as a specific type of issue frame, i.e., framing the topic of concern, that actors use in communicative contexts, in addition to other frames, such as identity frames, i.e., framing one's own identity, characterization frames, i.e., characterizing other stakeholders, or power frames, i.e., framing the power relations of the actors involved (Gray 2003).

Kurtz (2003:894) makes a distinction between scale frames and counter-scale frames. "Scale frames are the discursive practices that construct meaningful (and actionable) linkages between the scale at which a social problem is experienced and the scale(s) at which it could be politically addressed or resolved." She uses the term counter-scale frame to "refer to an action frame intended to undermine the resonance and persuasiveness of a given scale frame" (Kurtz 2003:907).

\section{METHODS}

\section{Methodological approach}

We used an interpretive approach (Yanow 2000, Yanow and Schwartz-Shea 2006) to study the scale frames of the different actors. Interpretive methods were based on the presupposition that we live in a social world characterized by the possibility of multiple interpretations (Yanow 2000). Interpretive researchers try to understand the way in which people, or groups of people, give meaning to specific events (Van Bommel 2008).

We see our case and analysis as a powerful example of an in-depth scale frame study from which we can learn about the implications of scale framing in complex policy processes in other contexts (see Flyvbjerg 2006). 


\section{Data collection}

We analyzed our case by means of:

- Seventeen semistructured interviews. Semistructured interviews do not follow a prefixed list of questions but allow for a conversation based on predetermined themes (e.g., Silverman 2001). We interviewed representatives of all involved parties, i.e., politicians, civil servants, farmers, citizens, action group.

- Studying four important moments in the municipal decision making process, i.e., council meetings about the ADA and/or the $\mathrm{NMC}$, in which the different stakeholders interacted.

- Studying policy documents, newspaper articles, and reports.

\section{Data analysis}

The conversations and council meetings were audio-taped and typed out verbatim. The transcripts of the interviews and council meetings were repeatedly read and compared. The contents of the transcripts were coded, using software for qualitative data analysis (Atlas-ti). Parts of the coded texts were subsequently categorized, analyzed, and interpreted using the theories and concepts discussed in the previous section.

The first step in our analysis was to read the transcripts looking for words, phrases, etc., that could possibly point toward scale-related issues; for example, words such as scale, scale effect, largescale, scale-up; words related to time, referring to time scales; words relating to spatial or administrative areas; words relating to the size of the farm, etc. Subsequently, we coded the quotations around these words as different scale frames in Atlas-ti. Scale frames were deployed throughout the different interviews and formed $27 \%$ of the coded quotations (17 conversation transcripts, in which 1,529 quotations were coded, of which 408 with scale-related codes; the council meetings were only coded for scale frames). Next we looked in detail at how the respondents built up their frames, and we made interpretations of the arguments they presented.
To ensure a systematic analysis, we made a theoretical division of spatial, administrative, agricultural, and time scales (see Table 1). This is a theoretical division because these scales are not completely separable: sometimes they coincide, sometimes they overlap, and sometimes they conflict. In other words, these scales map the world in different ways, but they do relate to each other.

To illustrate the different scale frames used by the different actors, we analyzed the stories of three key actors in the case: the alderman, the founder of the local action group, and the chicken farmer in the NMC consortium (Appendices 2, 3, 4). These key actors can be seen as representing the main groups in the process, and their quoted citations were chosen because they are the best examples to illustrate our results. To illustrate the implications of scale frames with regard to inclusion and exclusion, we analyzed four council meetings (Appendix 5) and reconstructed the decision making process (Appendix 1).

\section{RESULTS}

In the following, we present the scale frames of three key actors and subsequently the analysis of the scale frames in the decision making process.

\section{The alderman}

The alderman repeated several times during our conversation that it is essential "to find a balance," by concentrating intensive animal husbandry in ADAs, and providing opportunities for other rural functions in other areas of the municipality (see Appendix 2 and Table 2). The dominant frame deployed by the alderman emphasizes the importance of "sustainability on a higher level" as an argument for the developments in the agricultural sector. Concerning the area vision for the ADA, building on his sustainability argument, the alderman explained that he is of the opinion that it is a good vision document, because it provides "future-proof sizes." These scale frames focus on the agricultural sector as a whole and on intensive agriculture in general, rather than on the ADA and the NMC in the municipality, and on the opportunities offered by the concentration of intensive agriculture. 
Table 1. A theoretical division of scales.

\begin{tabular}{|c|c|c|}
\hline Scale & Levels & Utterances \\
\hline Spatial & $\begin{array}{l}\text { Neighborhood } \\
\text { Village } \\
\text { Municipal } \\
\text { Regional } \\
\text { National } \\
\text { Global }\end{array}$ & $\begin{array}{l}\text { - about (local, regional) developments } \\
\text { - about spatial issues e.g. landscape, the location of developments } \\
\text { - referring to certain villages, towns, cities, etc. }\end{array}$ \\
\hline Administrative & $\begin{array}{l}\text { Municipal } \\
\text { Provincial } \\
\text { National } \\
\text { EU } \\
\text { Global }\end{array}$ & $\begin{array}{l}\text { - about administrative matters } \\
\text { - referring to one of the administrative levels or concrete places in an } \\
\text { administrative context } \\
\text { - mentioning government, minister, provincial delegate, alderman, etc. } \\
\text { - discussing policy in general, the reconstruction act or another specific policy } \\
\text { - asking questions about who/which level is responsible }\end{array}$ \\
\hline Agricultural & $\begin{array}{l}\text { Crop } \\
\text { Field } \\
\text { Farm } \\
\text { Regional food system } \\
\text { Global food system }\end{array}$ & $\begin{array}{l}\text { - (scale) size of farms } \\
\text { - agriculture } \\
\text { - food production }\end{array}$ \\
\hline Time & $\begin{array}{l}\text { Past } \\
\text { Present } \\
\text { Future }\end{array}$ & $\begin{array}{l}\text { - about time } \\
\text { - about pace } \\
\text { - about the timeframe }\end{array}$ \\
\hline
\end{tabular}

The alderman used mainly spatial and agricultural scales to phrase his arguments about the establishment of the NMC and the development of the ADA (Table 2).

The alderman stressed the advantages of developments like the ADA and the NMC on mostly regional and higher scale levels, stating that we have to look at the higher levels to solve sustainability questions. In this way, he downplays the local level and the actors on that level. The other local developments, e.g., the sand-depletion installation, expansion of the fruit and vegetable auction, expansion of the greenhouses, which is the main argument of the action group, are no part of the alderman's story.

\section{The founder of the action group}

The founder of the local action group stated that this group does not have a problem with the ADA, but with the NMC (see Appendix 3 and Table 3). He started his argument by placing the establishment of the NMC in a broader local perspective, explaining that the village is surrounded by different developments, which by themselves are not such a threat, but altogether it is felt that the village is being enclosed by these developments. In his enumeration, he continually repeated the argument of the positive effect the individual developments may have on a higher administrative or spatial scale level, but its negative effects on the local level. In other words, he stressed the other developments on the local level to construct the argument that the accumulation of negative effects of the developments is unacceptable; i.e., "local accumulation scale frame." $\mathrm{He}$ used the accumulation of the negative effects of the developments together to neutralize the argument that the initiatives by themselves are positive developments. In addition to the local level, he stressed the global level, to contest the advantages on the national level by mentioning disadvantages for the rainforest in Brazil and far larger farms in Ukraine, to construct his arguments against the ADA and the NMC. This we refer to as "unsustainability on the global level scale frame." 
Table 2. The scales and levels used by the alderman.

\begin{tabular}{llll}
\hline \hline $\begin{array}{l}\text { What is being } \\
\text { framed }^{[1]}\end{array}$ & How is this framed & Scale & Level
\end{tabular}

\begin{tabular}{lll}
\hline NMC & $\begin{array}{l}\text { As causing environmental Spatial } \\
\text { inconvenience only in its } \\
\text { close surroundings }\end{array}$ & Neighborhood
\end{tabular}

Look, in the end because we'll concentrate we'll realize an environmental gain. [...] Only on the Dutch scale, on the European scale, on the provincial scale, on the municipal scale that's right, but somewhere something [NMC] is being developed that in those surroundings leads to an increase.

NMC

As inevitably resulting in Spatial local disadvantages in order to solve issues at other locations

NMC

As beneficial/ advantageous for the community, the surrounding area

NMC

As creating more sustainability by solving bottlenecks somewhere else

ADA

As a development in the municipality that will solve regional sustainability questions

ADA

As a development to transform the rural areas, to balance the different functions in the rural areas

Spatial

Spatial

Spatial Regional

Agricultural intensive cattle breeding

ADA
As providing space for future-proof farms
Agricultural/ Time
Municipal/ Regional

Neighborhood/ Regional

Municipal

Regional

The moment you live next to the ADA, [...] then in your environment, something [NMC] will come that will increase certain things. [...], and in another area you will have a decrease.

The first advantages are clearly advantages for the community. People from the municipality move to the ADA, so somewhere else in the municipality a farm is cleared. [..]Thus, for the people, the surrounding area, for nature, for ecology, the environment will improve.

The strength of the concept [NMC] I think is that you solve bottlenecks somewhere else, in nature areas. And [...] I find this something with a great degree of sustainability.

I think it's important that we dared to choose to think more broadly beyond our own municipality. Otherwise such developments won't succeed. And if we want to solve sustainability questions then you'll have to dare to look further than your own church steeple.

...but it's important, you've got to do this [develop the ADA], but in other places you've got to clear out things. Then you'll have the balance again.

The fact that you want to concentrate more, everything in larger areas [...], ADAs, and also simply developing the instruments to transform the remainder of the rural area. Thus cleaning up old farm buildings, glasshouses, strengthening nature, openness, those things. That's, well, finding the balance.

Regional food $\quad A n A D A$ is an industrial area for intensive cattle system breeding.

Regional food The criteria: 6 ha, $65 \%$ covered with buildings, system/ those are future-proof sizes.

\footnotetext{
${ }^{[1]}$ In this table, all the scale frames with regard to the agricultural development area (ADA) and the new mixed company (NMC) deployed by the alderman in the interview are included. The selected quotations are in italics. We translated the quotes as literally as possible. Additions and changes are indicated by square brackets.
} 
Using spatial, administrative, and agricultural scales and levels, the founder of the local action group portrayed the NMC as a bad development on multiple scale levels. (For a visual illustration see http://www.youtube.com/watch?v=MyahOyDxM44 ).

\section{One of the entrepreneurs}

One of the entrepreneurs argued that concepts like the NMC are an inevitable part of the future of intensive agriculture (see Appendix 4 and Table 4). The entrepreneur framed the development of the NMC on a spatial scale, at the regional rather than the local level. There is a chance that the entrepreneur will establish the NMC in the Netherlands, but there are also other possibilities. The entrepreneur was of the opinion that Dutch society is about to decide on the future of intensive agriculture and the future of food production (time scale frame). He made it seem as if he does not really care whether and where the NMC will be established in the Netherlands, as long as the concept of the NMC is established somewhere. If not here, then he will go somewhere else, for example, to India where he is already involved in a project. Stating it this way, the entrepreneur gives the creation of the NMC an importance that goes beyond the ADA, municipality, or province; he puts the development on the national level of the spatial scale.

In line with this reasoning, the entrepreneur framed the NMC as "a very sustainable concept for future intensive agriculture, an example for the rest of the world" that exceeds personal, local, or national interests. By taking his argument one step further, reasoning that the importance of the project is so great that the specific location is not the point of discussion, "if not here, then somewhere else", he keeps out of harm's way. In other words, he depersonalizes the issue and at the same time excludes the citizens, the local action group, and even the local administration from the issue.

The entrepreneur was of the opinion that the NMC will improve the situation on higher spatial levels and will only cause slightly more trouble on the local level. Therefore, the entrepreneur does not ignore the effects on the local level, he rather downplays them. The other developments around the village, which worry the founder of the action group, are no part of the story of the entrepreneur.
For the entrepreneur, the discussion was about the NMC, not about the ADA. In contrast to the founder of the local action group, the entrepreneur used several scales and levels to show how good the development of the NMC is.

\section{The decision making process}

The analysis of the different council meetings (see Appendix 5) shows that the different speakers used different scales and levels to frame the NMC and ADA. In all the meetings, the arguments made by the citizens and representatives of different groups and organizations were hardly addressed in the political debate. The citizens discussed the NMC, whereas the political debate was about the area vision for the ADA: a scale frame mismatch between the agricultural and spatial scale. We see that different parties commented on the mixing-up of the discussion about the NMC and the development of the ADA, but nothing was done about this. The fact that the political debate was not about the concerns of the citizens with regard to the NMC, but only about the criteria in the area vision, led to citizens having the feeling that they were not being listened to, resulting in commotion and discontent. As a consequence, the action group was founded, and media attention was attracted to make the concerns public. Both the action group and media attention led to several delays and obstructions of the decision making process.

Although it seemed that the different actors were discussing the same topic in the meetings, they used different arguments built on different scale frames, which they didn't explicate. The analysis shows that scale frame differences and mismatches occur; different actors, although discussing the same topic but using different scale frames, talk at cross purposes. As a consequence, we saw the different actors repeating their arguments in each subsequent meeting, resulting in tenacity and even conspiracy.

The scale frames deployed in the meetings were comparable to the scale frames deployed by the key actors in the interviews. In the meetings, the "regional balance scale frame," the "future-proof scale frame," the "sustainability on a higher level scale frame," the "local accumulation scale frame," and the "global unsustainability scale frame" as deployed above were repeatedly brought to the fore. Particularly the "sustainability on a higher level scale frame" was recognized throughout the 
Table 3. The scales and levels used by the founder of the action group.

\begin{tabular}{|c|c|c|c|c|}
\hline $\begin{array}{l}\text { What is being } \\
\text { framed }^{[1]}\end{array}$ & How is this framed & Scale & Level & Quote \\
\hline NMC & $\begin{array}{l}\text { As a degradation for } \\
\text { the region, a win-win } \\
\text { situation nationally }\end{array}$ & Spatial & Regional/ National & $\begin{array}{l}\text { For the region it [NMC] is still a degradation. } \\
\text { You can read that in the [consultancy name] } \\
\text { environmental advice. On the national scale } \\
\text { there is a win-win situation. }\end{array}$ \\
\hline
\end{tabular}

NMC

As a development that is too large for the landscape in a country as small as the Netherlands

ADA

ADA

NMC

As desired by all administrative levels

As one of the accumulating developments that will transform the village into a neighborhood in an industrial park

As one of many in itself possibly good developments

Spatial

Spatial

Village

National

Spatial

We're a very small country in which open space is claimed for very many things, [...] and since we're such a small country there simply is no space for developments like this [NMC].

...but as a result of all those developments [the village] is basically placed in an industrial park, a neighborhood in an industrial park.

Administrative

Municipal/ Provincial/ National

As causing trouble

Agricultural

Farm

As disastrous for small family farms

NMC

As questionable if pork production is desirable

NMC

As too small to compete with farms in other countries

NMC

As having
Agricultural Global food system

Agricultural Global food system
Agricultural Farm

Regional/ Global food system
And there again the thought: we have to concentrate the greenhouses, since that means that you have to affect the landscape at fewer places. Only that doesn't seem to count for [this village].

Looking at the decision making, we're not only talking about the municipality, but [...] on central, provincial, and municipal level the administrators are all Christian Democrats who already in 2003 have declared they'll do anything to develop the NMC. The minister was even willing to adapt the law.

Particularly the chicken farm will emit a gigantic lot of particulate matter.

Talking about the NMC, that's disastrous for small family farms.

It's questionable whether so much pork is desirable, since in principle there's an overproduction in the world and for sure the Netherlands, since 80 to $90 \%$ of the pork is exported [...] we state that more attention should be paid to regional production. [Western Europe].

In the end The Netherlands cannot win with this company on the world market.

If you watch what happens in South America, where gigantic soy plantations are put down and a large part of it is transported to feed the pigs here [...] all that pork is very unproductive. You should rather produce much more soy and vegetables and those kinds of things, then you need a smaller agricultural area for more nutrition. questionable sustainability from a nutrition point of view 


\begin{tabular}{|c|c|c|c|c|}
\hline NMC & $\begin{array}{l}\text { As should be } \\
\text { developing } \\
\text { knowledge for the } \\
\text { Third World and a } \\
\text { concept that will be } \\
\text { exported to China }\end{array}$ & Agricultural & Global food system & $\begin{array}{l}\text { Use the company [...] to develop knowledge } \\
\text { meaningful for the Third World, but in the Third } \\
\text { World these gigantic companies would never be } \\
\text { placed. What happens, these companies, the } \\
\text { concept is exported to China and in China they } \\
\text { will make the money. }\end{array}$ \\
\hline NMC & $\begin{array}{l}\text { As competing with } \\
\text { small farmers in } \\
\text { Ghana }\end{array}$ & Agricultural & Global food system & $\begin{array}{l}\text { In Ghana, chicken farmers don't have a chance } \\
\text { anymore. Why? What we consider as waste over } \\
\text { here, the chicken wings and the like, is dumped in } \\
\text { Africa for very low prices. }\end{array}$ \\
\hline
\end{tabular}

${ }^{[1]}$ In this table, all the scale frames with regard to the agricultural development area (ADA) and the new mixed company (NMC) deployed by the founder of the action group in the interview are included. The selected quotations are in italics. We translated the quotes as literally as possible. Additions and changes are indicated by square brackets.

different administrative levels, when the reconstruction or intensive cattle breeding was discussed (see Appendix 1). Using certain scale frames enabled actors to include some and exclude others from the decision making process. For example, the alderman, and administrators in general, by framing the issue on a regional or higher level, downplayed the actors on the local level and indirectly excluded them from the decision making process. The repeated use of certain typical scale frames also showed who was engaging with whom and which actors shared the same opinion. Furthermore, it showed that actors are not open to the scale frames of others.

\section{DISCUSSION AND CONCLUSIONS}

In this section, we compare the different scale frames used by the different actors, followed by a discussion on the implications of scale frames for policy processes and ideas for future research.

\section{The different scale frames compared}

Our study shows that the three key actors used different scales in their framings of the issue. The alderman used mainly spatial and agricultural scale frames in his reasoning. He used his dominant "sustainability on a higher level scale frame" to justify the negative effects and disadvantages of the development of an NMC at the local level. The founder of the action group also used multiple levels and scales, i.e., spatial, administrative, and agricultural, but he used these to highlight the downsides of the NMC. He used different scale frames to construct different arguments against the
NMC. His dominant scale frame can be characterized as "accumulation of local developments." The entrepreneur presented different scale frames relating to space, agriculture, and time to frame the development of the NMC as "an example of sustainable intensive agriculture for the rest of the world." Putting it this way, the entrepreneur placed the issue in a national or global perspective, emphasizing that the interests are far larger than his personal interests. For the entrepreneur, it was about the concept of an NMC and the future of intensive animal husbandry. The entrepreneur considered the NMC as a solution for future intensive animal husbandry because it solves problems relating to animal welfare and environmental issues. In contrast to the founder of the local action group, he used multiple scales to show how good the NMC is.

In the council meetings, the dominant scale frames as deployed by the three key actors were continuously brought to the fore and repeated by the other actors in the same configuration. By repeating, strengthening, and adding to each other's claims, frames become frozen, with the result that they become absolutely true for the people of the group who use them and therefore are put forward in no matter what context (Ford 1999, Gray 2003, Aarts and van Woerkum 2006).

We conclude that different actors use different kinds of scales to construct their specific scale frames, in which they highlight different levels. Therefore, in addition to, for example, identity frames or characterization frames (Gray 2003), scale frames are used to make sense in complex policy processes, emphasizing both the problem at stake and the direction in which the solution should be sought. Furthermore, our study shows that actors use and 
Table 4. The scales and levels used by the entrepreneur.

\begin{tabular}{|c|c|c|c|c|}
\hline $\begin{array}{l}\text { What is being } \\
\text { framed }^{[1]}\end{array}$ & How is this framed & Scale & Level & Quote \\
\hline NMC & $\begin{array}{l}\text { As a company } \\
\text { nobody in the village } \\
\text { will notice }\end{array}$ & Spatial & Village & Nobody in [the village] will even notice. \\
\hline NMC & $\begin{array}{l}\text { As a development } \\
\text { with which the } \\
\text { municipality can } \\
\text { show off }\end{array}$ & $\begin{array}{l}\text { Spatial/ } \\
\text { Administrative }\end{array}$ & Municipal & $\begin{array}{l}\text { I believe [the municipality], if the NMC is } \\
\text { established and is managed successfully, they } \\
\text { can well show off as an area where innovations } \\
\text { found their breeding ground, [...] I believe [the } \\
\text { municipality] should be proud of that! }\end{array}$ \\
\hline NMC & $\begin{array}{l}\text { As solving problems } \\
\text { at other places }\end{array}$ & Spatial & Regional & So I solve many problems in four other places. \\
\hline NMC & $\begin{array}{l}\text { As a company that } \\
\text { will be developed if } \\
\text { not here then } \\
\text { somewhere else }\end{array}$ & Spatial & National & $\begin{array}{l}\text { And there is a big chance we'll do it here in the } \\
\text { Netherlands. }\end{array}$ \\
\hline NMC & $\begin{array}{l}\text { As determined by the } \\
\text { size of the smallest } \\
\text { feasible abattoir }\end{array}$ & Agricultural & Farm & $\begin{array}{l}\text { The size is solely determined because we'll } \\
\text { build the smallest abattoir that can cost- } \\
\text { effectively slaughter chickens. }\end{array}$ \\
\hline NMC & $\begin{array}{l}\text { As a beautiful, } \\
\text { innovative company }\end{array}$ & Agricultural & Farm & $\begin{array}{l}\text { Moreover I wanted to practice transparency and } \\
\text { situate the company on a spot where everybody } \\
\text { can see it. [...] Well I want to make there a } \\
\text { beautiful, innovative company, which you can } \\
\text { show and you don't have to be ashamed of. }\end{array}$ \\
\hline NMC & $\begin{array}{l}\text { As being better than } \\
\text { the old small farms }\end{array}$ & Agricultural & Farm & $\begin{array}{l}\text { The requirements for building a new company } \\
\text { are so strict that a company with } 1.2 \text { million } \\
\text { animals causes less environmental damage than } \\
\text { currently one with 120,000. Thus, yes I'm } \\
\text { convinced it'll be better. }\end{array}$ \\
\hline NMC & $\begin{array}{l}\text { As an example for } \\
\text { the rest of the world }\end{array}$ & Agricultural & Global food system & $\begin{array}{l}\text { I think this is an example... that the importance } \\
\text { goes beyond my personal interest and also } \\
\text { beyond the interest of intensive animal } \\
\text { production. } \\
\text { We want to create an appealing project there, } \\
\text { which can serve as a model for the world. This } \\
\text { isn't only about us. } \\
\text { Moreover we are convinced the concept we've } \\
\text { developed really is an important example for the } \\
\text { world. } \\
\text { Many people don't see the larger importance of } \\
\text { the development we're putting into action. } \\
\text { We're indeed very early, which is a good thing, } \\
\text { since otherwise this development might well } \\
\text { come to a dead end and that would be a great } \\
\text { loss for the Dutch sector, and worldwide as } \\
\text { well, I believe. }\end{array}$ \\
\hline NMC & $\begin{array}{l}\text { As causing 5\% less } \\
\text { loss of raw materials }\end{array}$ & Agricultural & Global food system & $\begin{array}{l}\text { Which means we lose } 5 \% \text { less raw materials in } \\
\text { the chain, which isn't so important for the } \\
\text { Netherlands, but looking at the world that's of } \\
\text { very great importance. }\end{array}$ \\
\hline NMC & $\begin{array}{l}\text { As the future of } \\
\text { intensive agriculture }\end{array}$ & Time & Future & $\begin{array}{l}\text { Does your vision [...] mean that this [the NMC] } \\
\text { is the way to go for sustainable intensive } \\
\text { agriculture? } \\
\text { I think it's unavoidable [...] }\end{array}$ \\
\hline
\end{tabular}




\begin{tabular}{l} 
NMC $\begin{array}{l}\text { As a possibility for } \\
\text { future intensive } \\
\text { animal production } \\
\text { that Dutch society is } \\
\text { about to decide upon }\end{array}$ \\
$\begin{array}{l}\text { Time } \\
{ }^{[1]} \text { In this table, all the scale frames with regard to the agricultural development area (ADA) and the new mixed company (NMC) } \\
\text { deployed by the farmer in the interview are included. The selected quotations are in italics. We translated the quotes as literally as } \\
\text { possible. Additions and changes are indicated by square brackets. }\end{array}$ \\
\hline
\end{tabular}

mix multiple scales and levels, and not only the spatial scale as studied in human and political geography (Delaney and Leitner 1997, Marston 2000, Brenner 2001, Kurtz 2003, Harrison 2006). They frame their arguments as convincingly as possible and from different points of view, implying that they have thoroughly considered their standpoint. Following Kurtz, the frames of the alderman, politicians, and policy makers on higher levels together with the entrepreneur(s) on the one hand, and the frames of the action group and citizens on the other hand, relate to each other as scale frames and counter-scale frames. If we take the analysis a step further however, these scale frames and counter-scale frames consist of different scale dimensions, e.g., spatial, agricultural, administrative, and time scales, that highlight different aspects of the issue and are positioned on different levels. The use of differently mixed scales and levels enables more arguments, provides a structure for arguments, but also tends to obscure the interests at stake. Actors try to legitimate their positions by juggling scale frames but do not take on board the scale frames and arguments of others with opposing opinions. The analysis of the council meetings shows that certain configurations of actors use and stick to the same, frozen, scale frames. The use of these various different scale frames can be explained as actors speaking different languages, expressed in different frames, resulting in incompatible stories that fit diverging interests (Pearce and Littlejohn 1997). As a result of the use of different scale frames without explication, scale frame mismatches occur.

\section{Scale frame mismatches}

We conclude that, in addition to scale mismatches (see for example Borgström et al. 2006, Cumming et al. 2006, Termeer et al. 2010a), we can speak of scale frame mismatches. We identify three types of scale frame mismatches: (1) framing the issue using different scale frames, (2) framing the issue using different scales, and (3) framing the issue at different levels of the same scale. Because we only selected scale frames for the analysis, i.e., where issues are framed using a certain scale and/or level, all of these involve more than merely issue framing mismatches. However, not all the differences between the scale frames are mismatches; we refer to scale frame mismatches when the scale frames deployed by different actors point in varying directions, making decision taking problematic.

\section{Framing the issue using conflicting scale frames}

In the context of this local decision making process, for example, both the founder of the action group and the farmer framed the issue using the global food system level on the agricultural scale. However, they did so in conflicting ways. The founder of the action group implied that the NMC's sustainability is questionable, "If you watch what happens in South America, where gigantic soy plantations are cut down and a large part of it is transported to feed the pigs here [...] You should rather produce much more soy and vegetables and those kinds of things, then you need a smaller agricultural area for more nutrition." The farmer, however, framed the NMC as "an example for the world." Therefore, the scale frame of the founder pointed in the direction of developing small-scale regional food production instead of NMCs, whereas the farmer was of the opinion that concepts like the NMC provide solutions for sustainable food production worldwide.

\section{Framing the issue on different scales}

The alderman and the farmer, for example, framed the NMC as solving bottlenecks/problems 
somewhere else. The alderman stated, "The strength of the concept [NMC] I think is that you solve bottlenecks somewhere else, in nature areas" and the farmer comparably said, "So I solve many problems in four other places," both using a spatial scale, regional level. According to the founder of the action group, instead of solving problems, the NMC "is disastrous for family farms," thereby using an agricultural scale, farm level.

\section{Framing the issue at different levels of the same scale}

The alderman, for example, framed the NMC on the spatial scale, neighborhood level, as causing environmental inconvenience only in its immediate surroundings. "Look, in the end because we'll concentrate we' ll realize an environmental gain. [...] Only on the Dutch scale, on the European scale, on the provincial scale, on the municipal scale that's right, but somewhere something [NMC] is being developed that in that surrounding leads to an increase." The founder of the action group, however, framed the NMC as a win-win situation on the national level, but a degradation for the region, emphasizing the regional and national level, "for the region it [NMC] is still a degradation. You can read that in the [consultancy name] environmental advice. On the national scale there is a win-win situation."

\section{Implications of scale frame mismatches for complex policy processes}

Our analysis shows how actors use scale frames to legitimize the exclusion of certain actors and/or ideas from the conversation and to invalidate certain arguments in the discussion. Framing the issue on a particular scale and level makes it possible, consciously or unconsciously, to include and exclude arguments and other actors without literally saying so. The alderman, for example, excluded the local citizens by framing the issue not on the local, but on regional and national scale levels. Also, the use of the local level by the founder of the action group allowed him to include other local developments in his argument as well.

Looking at the evolving policy process, we can observe relations between the identified scale frames and different process stages. An example of the use of a particular scale frame that has implications for the process is the framing by the alderman, and the council more generally, of the NMC as a positive and sustainable agricultural development. Because the alderman was already positive before the official debate on the development of the ADA started, this agricultural scale frame has influenced the municipal decision making process from design to decision. On the other side, citizens only discussed the NMC whereas the formal debate was about the area vision, including the ADA. Throughout the process, this made it easy for the alderman to consider the arguments as irrelevant and consequently exclude these arguments, while at the same time he did not have to debate the NMC. By defining the worries of the citizens with regard to animal welfare and health as part of a national debate, the alderman shifted responsibility for this debate to the national level and at the same time excluded these arguments from the local discussion.

Another type of implication follows from the scale frame mismatches that we have identified. As a result of scale frame mismatches, communication problems occur, but the strategic use of scale frames also provides opportunities for change. We can make a distinction between scale frame differences and scale frame mismatches. Scale frame differences are not problematic per se; on the contrary, they may allow for enrichment of the debate and change. Scale frame mismatches, on the other hand, imply difficulties and conflict. In the following, we discuss the implications of scale frame differences and mismatches, based on negotiation and communication theory, because this seems an important issue for further research.

In the negotiation literature, a distinction is made between distributive negotiating and integrative negotiating (e.g., Pruitt and Carnevale 1993, Aarts and van Woerkum 2002). Distributive negotiating is about "one cake that has to be divided," and integrative negotiating is about "the baking process," about jointly baking a larger cake (Pruitt and Carnevale 1993). In the former, actors keep motives, interests, and feelings to themselves, and knowledge is translated into arguments that are used as weapons in the struggle to achieve the maximum result. Scale frame mismatches fit this negotiation style. The latter is about openness, joint fact finding, and social reflection (e.g., Pruitt and Carnevale 1993, Aarts and van Woerkum 2002). Scale frame differences fit with this style. 
In the decision making process that we have studied (see Appendix 1), scale frame mismatches play a role in the stagnation of the communication between the actors in the process and consequently play a role in the stagnation of the policy process as a whole. We can look at this particular decision making process as a distributive negotiation process. When actors involved in multistakeholder problems do not make their interests explicit, and instead emphasize different scales and different levels to undercut the arguments of the other parties, the meaning of the issues and the delimitation of the problem domain remain contested. In other words, the question, 'what are we coconstructing together? ' is neither asked nor answered. No joint fact finding, social reflection, or reframing takes place. Instead, through processes of positive feedback within their own groups, the scale frames are continuously repeated and strengthened (see also Termeer et al. $2010 b$ ), resulting in an unstable distributive process (Pruitt and Carnevale 1993), frozen frames (Gray 2003), fixations of the process (Termeer and Kessener 2007), and the problem becoming intractable (Morgan 1998, Gray 2004). This complicates the discussion and decreases the space for negotiation. It resembles the stagnating effects on policy processes of so-called dialogues of the deaf (van Eeten 1999).

In our case, the area vision was approved in February 2008, but, as of August 2010, the initiators of the NMC do not yet have permission to start building. The opponents continue to obstruct the process, using their "accumulation on the local level scale frame," by requesting more and more studies to prove the accumulated effects and to question the assumed sustainability. Furthermore, using the "accumulation on the local level scale frame" and the "unsustainability on the global level scale frame," the opponents have been able to involve national campaigning groups and to create a media hype. By obstructing the process on the local level, the alderman is made responsible, and the province and central government are no longer involved, but the process is difficult to continue and complete without the support of higher administrative levels and their resources.

To conclude, we argue that, in addition to research on dealing with scale mismatches, further research on scale frame mismatches and the implications thereof is needed. Looking at policy processes as negotiations, we need more insights into the role of scale frames, scale frame differences, and scale frame mismatches in interaction. Being reflexive about scale frames, so as to enable joint fact finding and reframing, might prove to be an important ingredient for scale-sensitive governance.

Responses to this article can be read online at: http://www.ecologyandsociety.org/voll6/iss l/art38/ responses/

\section{Acknowledgments:}

We would like to thank the two anonymous reviewers for their many detailed comments, which helped us to improve earlier versions of this paper. This paper was written in the context of the IP/OP 'Scaling and Governance' Research Program, which has been spearheaded by Wageningen University and Research Center (Wageningen UR), as part of its mission to contribute to solutions for the most pressing global environmental problems.

\section{LITERATURE CITED}

Aarts, N., and C. van Woerkum. 2002. Dealing with uncertainty in solving complex problems. Pages 421-435 in C. Leeuwis and R. Pyburn, editors. Wheelbarrows full offrogs: social learning in rural resource management. Koninklijke Van Gorcum, Assen, The Netherlands.

Aarts, N., and C. van Woerkum. 2006. Frame construction in interaction. Pages 229-238 in Engagement. Proceedings of the 12th MOPAN International Conference, 22-24 June, University of Glamorgan, Pontypridd. Short Run Press, Exeter, UK.

Adger, W. N., K. Brown, and E. L. Tompkins. 2005. The political economy of cross-scale networks in resource co-management. Ecology and Society 10 (2): 9. [online] URL: http://www.ecologyandsociety. org/vol10/iss2/art9/.

Bateson, G. 1972. Steps to an ecology of mind. Ballantine Books, New York, New York, USA.

Berkes, F. 2006. From community-based resource management to complex systems: the scale issue and marine commons. Ecology and Society 11(1): 
45. [online] URL: http://www.ecologyandsociety.org/ vol11/iss 1/art45/.

Biggs, R., C. Raudsepp-Hearne, C. AtkinsonPalombo, E. Bohensky, E. Boyd, G. Cundill, H. Fox, S. Ingram, K. Kok, S. Spehar, M. Tengö, D. Timmer, and M. Zurek. 2007. Linking futures across scales: a dialog on multiscale scenarios. Ecology and Society 12(1): 17. [online] URL: http://www.ecolog yandsociety.org/vol12/iss11/art17/.

Borgström, S. T., T. Elmqvist, P. Angelstam, and C. Alfsen-Norodom. 2006. Scale mismatches in management of urban landscapes. Ecology and Society 11(2): 16. [online] URL: http://www.ecolog yandsociety.org/vol11/iss2/art16/.

Brenner, N. 2001. The limits to scale? Methodological reflections on scalar structuration. Progress in human geography 25:591-614.

Buizer, I. M., B. Arts, and K. Kok. 2011. Governance, scale, and the environment: the importance of recognizing knowledge claims in transdisciplinary arenas. Ecology and Society 16(1): 21. [online] URL: http://www.ecologyandsociety.org/ vol16/iss 1/art21/.

Cash, D. W., W. Adger, F. Berkes, P. Garden, L. Lebel, P. Olsson, L. Pritchard, and O. Young. 2006. Scale and cross-scale dynamics: governance and information in a multilevel world. Ecology and Society 11(2): 8. [online] URL: http://www.ecology andsociety.org/vol11/iss2/art8/.

Cumming, G. S., D. H. M. Cumming, and C. L. Redman. 2006. Scale mismatches in socialecological systems: causes, consequences, and solutions. Ecology and Society 11(1): 14. [online] URL: http://www.ecologyandsociety.org/vol11/iss1/ art14/.

Delaney, D., and H. Leitner. 1997. The political construction of scale. Political Geography 16:93-97.

Dewulf, A., B. Gray, L. Putnam, R. Lewicki, N. Aarts, R. Bouwen, and C. van Woerkum. 2009. Disentangling approaches to framing in conflict and negotiation research: a meta-paradigmatic perspective. Human Relations 62:155-193.

Dewulf, A., M. Mancero, G. Cárdenas, and D. Sucozhañay. 2011. The fragmentation and connection of frames in collaborative water governance. A case study of river catchment management in Southern Ecuador. International Review of Administrative Sciences 77:in press.

Entman, R. M. 1993. Framing: toward clarification of a fractured paradigm. Journal of Communication 43:51-58.

Fischer, F., and J. Forester, editors. 1993. The argumentative turn in policy analysis and planning. Duke University Press, Durham, North Carolina, USA.

Flyvbjerg, B. 2006. Five misunderstandings about case-study research. Qualitative Inquiry 12:219-245.

Folke, C., L. Pritchard, F. Berkes, J. Colding, and U. Svedin. 2007. The problem of fit between ecosystems and institutions: ten years later. Ecology and Society 12(1): 30. [online] URL: http://www.e cologyandsociety.org/vol12/iss1/art30/.

Ford, J. D. 1999. Organizational change as shifting conversations. Journal of Organizational Change Management 12:480-500.

Gibson, C. C., E. Ostrom, and T. K. Ahn. 2000. The concept of scale and the human dimensions of global change: a survey. Ecological Economics 32:217-239.

Goffman, E. 1974. Frame analysis: an essay on the organization of experience. Harper and Row, New York, New York, USA.

Goodin, R. E., M. Rein, and M. Moran. 2006. The public and its policies. Pages 3-35 in M. Moran, M. Rein, and R. E. Goodin, editors. The Oxford handbook of public policy. Oxford University Press, Oxford, UK.

Gray, B. 2003. Framing of environmental disputes. Pages 11-34 in R. J. Lewicki, B. Gray, and M. Elliott, editors. Making sense of intractable environmental conflicts: concepts and cases. Island Press, Washington, D.C., USA.

Gray, B. 2004. Strong opposition: frame-based resistance to collaboration. Journal of Community and Applied Psychology 3:166-176.

Hajer, M., and H. Wagenaar, editors. 2003. Deliberative policy analysis: understanding governance in the network society. Cambridge University Press, Cambridge, UK. 
Harrison, J. L. 2006. 'Accidents' and invisibilities: scaled discourse and the naturalization of regulatory neglect in California's pesticide drift conflict. Political Geography 25:506-529.

Kurtz, H. E. 2003. Scale frames and counter-scale frames: constructing the problem of environmental injustice. Political Geography 22:887-916.

Lebel, L., P. Garden, and M. Imamura. 2005. The politics of scale, position, and place in the governance of water resources in the Mekong region. Ecology and Society 10(2): 18. [online] URL: http://www.ecologyandsociety.org/vol10/iss2/ art18/.

Leitner, H. 2004. The politics of scale and networks of spatial connectivity: transnational interurban networks and the rescaling of political governance in Europe. Pages 236-255 in E. Sheppard and R. B. McMaster, editors. Scale and geographic inquiry. Blackwell Publishing, Hoboken, New Jersey, USA.

Lewicki, R. J., B. Gray, and M. Elliott, editors. 2003. Making sense of intractable environmental conflicts: frames and cases. Island Press, Washington, D.C., USA.

Lovell, C., A. Mandondo, and P. Moriarty. 2002. The question of scale in integrated natural resource management. Conservation Ecology 5(2): 25. [online] URL: http://www.consecol.org/vol5/iss2/art25/

Marston, S. A. 2000. The social construction of scale. Progress in Human Geography 24:219-242.

Morgan, G. 1998. Images of organization. Sage, Thousand Oaks, California, USA.

Olsson, P., C. Folke, V. Galaz, T. Hahn, and L. Schultz. 2007. Enhancing the fit through adaptive co-management: creating and maintaining bridging functions for matching scales in the Kristianstads Vattenrike Biosphere Reserve Sweden. Ecology and Society 12(1): 28. [online] URL: http://www.e cologyandsociety.org/vol12/iss1/art28/.

Papaik, M. J., B. Sturtevant, and C. Messier. 2008. Crossing scales and disciplines to achieve forest sustainability. Ecology and Society 13(1): 30. [online] URL: http://www.ecologyandsociety.org/vol13/ iss1/art30/.
Pearce, W. B., and S. W. Littlejohn. 1997. Moral conflict: when social worlds collide. Sage, Thousand Oaks, California, USA.

Pruitt, D. G., and P. J. Carnevale. 1993. Negotiation in social conflict. Open University Press, Buckingham, UK.

Rein, M., and D. Schön. 1996. Frame-critical policy analysis and frame-reflective policy practice. Knowledge and Policy 9:85-104.

Schön, D. A., and M. Rein. 1994. Frame reflection: toward the resolution of intractable policy controversies. Basic Books, New York, New York, USA.

Silverman, D. 2001. Interpreting qualitative data: methods for analyzing talk, text and interaction. Sage, Thousand Oaks, California, USA.

Stone, D. 1988. Policy paradox: the art of political decision making. Revised 2002 edition. Norton, New York, New York, USA.

Termeer, C. J. A. M., G. E. Breeman, M. van Lieshout, and W. D. Pot. 2010b. Why more knowledge could thwart democracy: configurations and fixations in the Dutch mega-stables debate. Pages 99-111 in R. J. in 't Veld, editor. Knowledge democracy: consequences for science, politics and media. Springer, Heidelberg, Germany.

Termeer, C. J. A. M., A. Dewulf, and M. van Lieshout. 2010a. Disentangling scale approaches in governance research: comparing monocentric, multilevel, and adaptive governance. Ecology and Society 15(4): 29. [online] URL: http://www.ecolog yandsociety.org/vol15/iss4/art29/.

Termeer, C. J. A. M., and B. Kessener. 2007. Revitalizing stagnated policy processes: using the configuration approach for research and interventions. Journal of Applied Behavioral Science 43:256-272.

Van Bommel, S. 2008. Understanding experts and expertise in different governance contexts. The case of nature conservation in the Drentsche Aa area in the Netherlands. Dissertation. Wageningen University, Wageningen, The Netherlands.

van Eeten, M. 1999. Dialogues of the deaf: defining new agendas for environmental deadlocks. Eburon, Delft, The Netherlands. 
van Lieshout, M., and N. Aarts. 2008. "Outside is where it's at!" Youth and immigrants' perspectives on public spaces. Space and Culture 11:497-513.

Weick, K. E. 1995. Sensemaking in organizations. Sage, Thousand Oaks, California, USA.

Yanow, D. 2000. Conducting interpretive policy analysis. Sage, Thousand Oaks, California, USA.

Yanow, D., and P. Schwartz-Shea, editors. 2006. Interpretation and method: empirical research methods and the interpretive turn. M. E. Scharpe, Armonk, New York, USA.

Young, O. 2006. Vertical interplay among scaledependent environmental and resource regimes. Ecology and Society 11(1): 27. [online] URL: http: //www.ecologyandsociety.org/vol11/iss1/art27/. 


\section{APPENDIX 1}

\section{Case description}

In the Netherlands, in order to restructure the rural areas to provide space for agriculture, nature, and water storage, the reconstruction act was formulated in 1999. One of the motives for this reconstruction was the 1997 the outbreak of the classic swine fever. Another motive was the number of functions the Dutch rural areas fulfill, resulting in competing claims and tensions. This is especially the case in the sandy areas in the south east of the Netherlands. In these areas, the intensive agricultural sector is large and nature is vulnerable. Environmental problems are more intense in these areas than in other parts of the Netherlands.

The reconstruction act is a national act decentralized to the provinces, which is executed and implemented by municipalities. This act divides the rural areas into three zones in which more or less intensive agriculture is allowed:

- in extensive areas (extensiveringsgebieden), the primary function is living or nature, and intensive farms have to leave,

- in intermediate areas (verwevingsgebieden), agriculture, housing, and nature are interwoven, and

- in agricultural development areas (ADAs) (landbouw ontwikkelings gebieden), intensive cattle breeding, settlement of new farms, and extending farms is possible. These development areas are designated by the provinces and established by the municipalities.

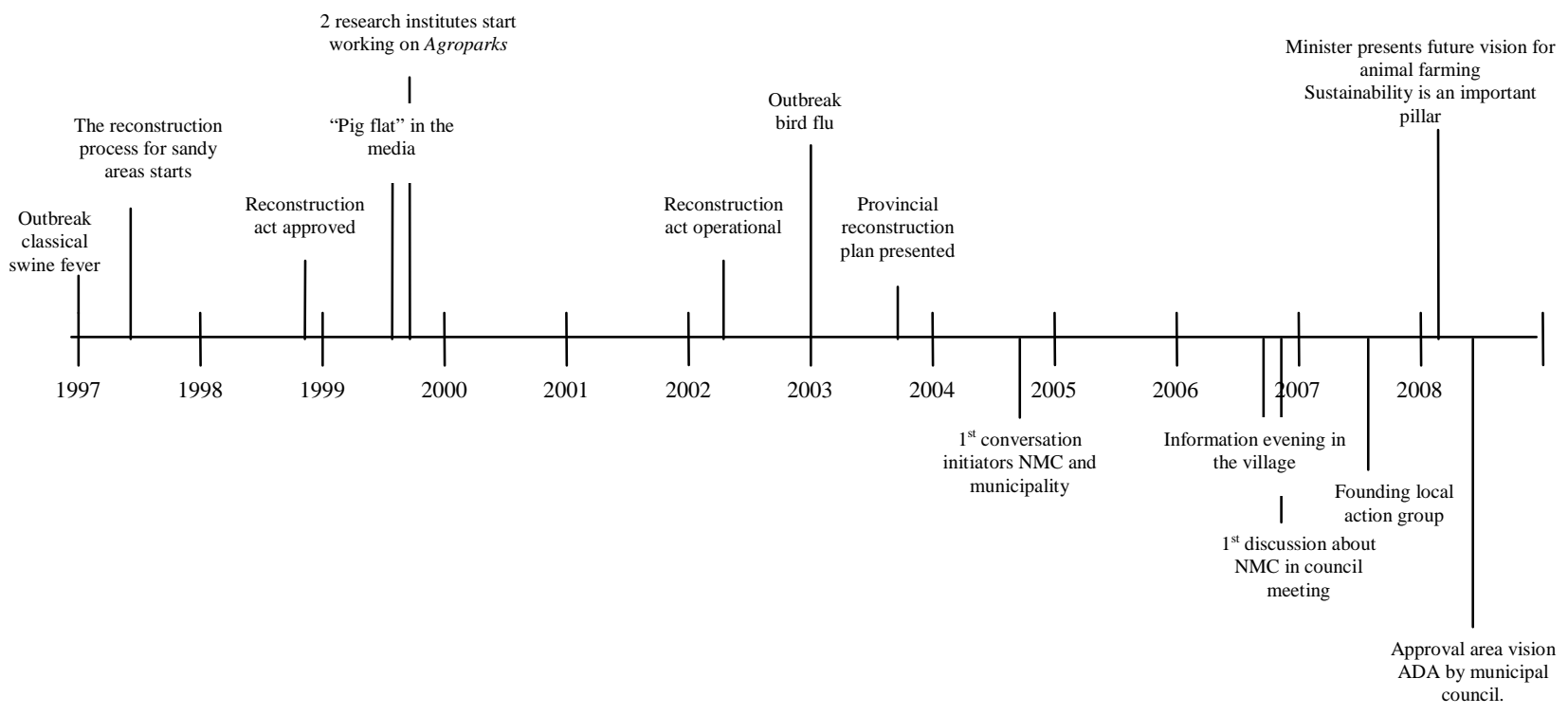

Figure A1.1: Reconstruction of the decision-making process (national and provincial events on top of timeline, municipal events below).

The municipality in our case has taken the first step in the establishment and development of an ADA by approving an area vision for the ADA. This vision document provides the framework of sizes, standards, rules, and regulations with which the farms in the ADA have to comply. For example, the percentage of the area that may be built upon, the standard for the odor that may be emitted, the heights of the buildings, etc., are described in this document. The approval of the area vision (on 12 February 2008) led to much commotion and fierce protests among citizens, fuelled by 
a local action group (see also Appendix 5). At the meeting where the municipal council voted on the approval of the area vision, both local and national newspapers, radio and television broadcasters were present.

In the ADA, a new mixed company (NMC) - also referred to as mega farm - wants to settle. Mixed company refers to older farming systems that combined cattle breeding and arable farming. The NMC will accommodate 3,700 sows, 9,700 pigs, 19,700 hogs, 1,200,000 chicks, and 74,000 chickens The farm will have its own manure fermentation installation, hatchery, and abattoir. The pig farm and chicken farm will be located in separate buildings of not more than one storey high. The initiators are planning to apply the latest technology, innovations, and far-reaching co-operation (for example providing their energy to mushroom growers in the area or households nearby) to be able to turn the farm into a closed system, using short chains, and thereby establish a sustainable new company. The citizens of the village where the ADA will be situated and a local action group are afraid for an increase in traffic, stench, particulate matter, and zoonotic infections. 


\section{APPENDIX 2}

\section{Narrative of the alderman}

We translated the quotes as literally as possible. Additions and changes are indicated by square brackets.

The responsible alderman was born and raised in the village close to the ADA, but not the one where the protest is concentrated. He has an agricultural background and this is his first term as an alderman with the Christian Democrats party, which is traditionally a party backed by many farmers. The alderman is enthusiastic about the NMC initiative and states

In the beginning, I associated myself too much with the NMC, I didn't do that well. That's why during the process I continuously had the label of proponent.

The alderman characterizes the future of agriculture in the area as "proceeding towards more intensive breeding" because of "the pressure on land in the Netherlands and as a result of the rising costs of property". According the alderman "the complexity of formal regulations and the risks for entrepreneurs" will lead to a certain scale-size of the farms. In his opinion, the development of agriculture of certain scale-sizes needs to be accommodated, and it is this accommodation that provides opportunities to transform the remaining of the rural areas: By "cleaning up old farm buildings, glasshouses, etc., values such as nature and openness" in those areas are strengthened. In addition to this development, the alderman also sees future opportunities for smaller farms combined with recreation and care functions.

The alderman repeats several times during our conversation that it is essential "to find a balance," that is, by concentrating intensive agriculture in ADAs, providing opportunities for other rural functions in other areas of the municipality (spatial scale frame, municipal level). The dominant frame deployed by the alderman emphasizes the importance of sustainability and the need to look at higher levels (than the farm or village) to solve sustainability questions. This scale frame focuses on the agricultural sector as a whole and on intensive agriculture in general, rather than on the ADA and the NMC in the municipality, and on the opportunities offered by the concentration of intensive agriculture. For example:

By bringing different functions together [in development areas] you can create a high amount of sustainability. Output is input. And all of this in such a setting that we will get real quality, both in the buildings and around the buildings.

and

The strength of the concept I think is that you solve bottlenecks somewhere else, in nature areas. And I, I say this now with a somewhat technical background, I find this something with a large degree of sustainability, the use of the newest techniques, less transport.

We could classify this "sustainability on a higher level scale frame" as an agricultural or spatial scale frame, regional food system, or regional level. The alderman deploys this scale frame as an argument for the developments in the agricultural sector, which he presents as facts: this is the way the future of agriculture is going to be. In the first quote, the alderman explains his perspective on 
sustainability. In the second quote, he expands his perspective. The alderman needs this sustainability perspective in his further reasoning about why the developments regarding the ADA and the NMC in his municipality are good.

Concerning the area vision, building on his sustainability argument, the alderman explains that he is of the opinion that it is a good vision document, because it provides "future-proof sizes" (time scale frame, future level). Furthermore he thinks that

it is important that we have dared to choose to think more broadly than our own municipality, otherwise such developments won't succeed. And if we want to solve sustainability questions then you will have to dare to look further than your own church steeple. For if everyone wants to do good around his own church steeple, you don't realize anything at all. While sometimes you will have a plus somewhere to be able to solve a very large minus elsewhere, or the other way around...

These phrases show how the alderman constructs the scale frame of sustainability on a higher level on the spatial scale and how he constructs the municipal level (or higher) as the right level for sustainability. The alderman is convinced that if we want to solve sustainability questions we have to look beyond our immediate surroundings. Furthermore he constructs the village level as around the church steeple. (In Dutch the reference to the church steeple does not necessarily have a religious connotation. In this quote it rather refers to the capacity to look beyond one's own locality and interests.) The aldermen needs this administrative scale frame (the importance of looking at the larger scale for sustainability reasons), in order to justify what is happening on the local level:

Yes, there are disadvantages the moment you live next to the ADA, whether you live in [Village A], [Village B], [Village C], or [Village D], then in your environment, something will come that will increase certain things. In that area that will happen, and in another area you will have a decrease. 


\section{APPENDIX 3}

\section{Narrative of the founder of the action group}

We translated the quotes as literally as possible. Additions and changes are indicated by square brackets.

The founder of the action group lives in the same village as the alderman, so in one of the neighboring villages, but not the one where the protest is concentrated. He is a member of the socialist party and has been politically active in the municipality in the past. He explains his position as founder of an action group in a village other than the one in which he lives as follows:

I used to be on the municipal council, so I knew those developments. I protest not only in [this village], but also in [another village] and, if I have to, also in Amsterdam, that doesn't really matter when it is about an interest. That's how I came to [this village], since no initiatives had been started here in a long time.

He emphasizes that when citizens joined the group it was no longer a political organization, but an independent action group.

The founder states that the action group does not have a problem with the ADA, but with the NMC. He starts his argumentation by placing the establishment of the NMC in a broader local perspective, by explaining that the village is surrounded by different developments, which by themselves are not such a threat, but altogether it is felt that the village is being enclosed by these developments. The first development he mentions is the NMC. He refers to the reconstruction act, which "is in itself a good plan," to be able to concentrate on the inconvenience of intensive cattle breeding. "But at this location it will cause more inconvenience than was already the case." And if this were the only development, it would be alright, looking at the locations where farms are cleared and the situation will improve. But on the other side of the village, a sand-processing installation is planned, with the same argument: they can make several smaller installations at different locations, but then more villages will suffer from the inconvenience. "So that's exactly the same reasoning as with the NMC." Another development is an industrial zone, instead of the various small industrial areas that are now spread over the region. Also, a large auction complex is planning to spread out towards the border of the village, and a glasshouse area is about to be expanded.

And there again the thought: we have to concentrate the greenhouses, since that means that you will affect the landscape at fewer places. Only that doesn't seem to count for [this village]. [...] but as a result of all those developments [the village] is basically placed in an industrial park, a neighborhood in an industrial park.

The founder of the action group presents all the separate developments as facts to work towards his main argument in the last quote: that it is unacceptable that the village will end up as a "neighborhood in an industrial park". In his enumeration, he continually repeats the argument about the positive effect that the individual developments might have on a higher spatial scale level, but the negative effects of it on the village level, and he emphasizes that this does not seem to count in the decision-making process. The founder of the action group states that before decisions about different initiatives to concentrate developments are taken, one should look at the location for these 
concentrations, so that the possible accumulated effect will be taken into account ("accumulation spatial scale frame").

The founder continues by explaining the arguments that the action group has against the NMC. For each argument (e.g. odor, increased transportation, increase of fine dust, the consequences for public health because of dust and MRSA), he explains what is wrong with the argumentation of the municipality and entrepreneurs. He raises doubt about every proof or investigation of the proponents, by questioning the independence of the study and the reliability of the results. He does this by referring to other studies and scientists who prove the opposite or state that the effects of the techniques are not known yet. For example:

Particularly the chicken farm will emit a gigantic lot of particulate matter. Constantly it is said in the discussion that clear air systems would filter enough out of the air, so the emission could be limited. They say we can filter $80 \%$ to $90 \%$ out. Already 6 September 2007, during a meeting in [the village] by [Mister G. ] from Wageningen, he is also a professor over there I believe. He has indicated that those things do not exist at all, which can do that.

\section{And}

That particulate matter is harmful for human health isn't only said here by us, but 50 doctors here in the region have brought that out. [...] In the meantime, the RIVM has conducted research and in that study all items that we have emphasized have been confirmed factually. [The RIVM is the government institution for public health and the environment.]

By showing these different uncertainties and their proof, the founder of the action group implicitly formulates another criterion for the establishment of the NMC, namely, that more security is needed, especially with regard to health issues.

After asking about possible advantages of the NMC, the founder states:

For the region it is still a degradation. You can read that in the [consultancy name] environmental advice. On the national scale there is a win-win situation. (spatial scale frame, regional versus national level)

But after this recognition of the advantages, he starts to break down the different arguments. Subsequently, he questions the sustainability of the NMC by linking it to negative developments at the global level ("unsustainability spatial scale frame").

If you watch what happens in South America, gigantic soy plantations are established and a large part of it is transported to feed the pigs, which we subsequently eat. Whereas from a nutrition point of view, all that pork is very unproductive. You should rather produce much more soy and vegetables and those kinds of things, then you need a smaller agricultural area for more nutrition, for more calories, or minerals, or how you would name it. So if we talk about the 3 Ps you have to look at those things. [The 3 Ps are three pillars of sustainability: people, planet, and prosperity.] 
With this explanation, the founder of the local action group shows that the NMC is a bad development on multiple agricultural scale levels. (For a visual illustration see Appendix 6.) Another related argument raised by the founder is the landscape. He argues that the Netherlands is a small country with many claims on the available space and that this makes the country too small for such developments (spatial scale frame, national level). This contrasts with the argument of the alderman who states that developing an NMC will provide space for other functions in other places. Lastly, the founder argues that the NMC does not have a future since on a global agricultural scale level it will not be able to compete with farms in other countries (this is in contrast to the recognition of the win-win situation on the national level presented above).

In the end, the Netherlands can't win with this company on the world market. To mention one example: in the Ukraine they want to establish a farm, or probably it is already there, with 100,000 pigs. That's three times what they are planning here. 


\section{APPENDIX 4}

\section{Narrative of the entrepreneur}

We translated the quotes as literally as possible. Additions and changes are indicated by square brackets.

The chicken farmer who is part of the consortium of entrepreneurs in the NMC lives in another municipality in another province than where the ADA is located. His firm consists of several poultry farms at different locations that he manages together with two brothers. A couple of years ago, when they were looking at the future of their company, they came across the NMC initiative. They found that their ideas and their attitude fitted exactly with those of the other entrepreneurs and that being part of the NMC would take them and their company one step further in respect of their sustainability aims. In their own plans, the brothers were working towards short chain systems; meaning that they would produce chickens from egg to meat within their company and without transportation. Being part of the NMC would allow them to come a step nearer to a closed system, because it would enable them to reuse the manure as well (by fermenting it into gas and energy).

According to this entrepreneur, concepts like the NMC are the future of intensive agriculture, and a development in the direction of NMCs is inevitable:

I think it's unavoidable. And there is a big chance we'll do it here in the Netherlands. An alternative is that the Netherlands decides that intensive production can't take place here any longer. There are examples of that from the past. In Singapore they've done that. Then you'll get a totally different society. I think we should think about that very carefully if we want that. In fact in the national debate about intensive animal production, we have come to the conclusion that that is not the way to go, we'll have to do with intensive production.

This quote shows that the entrepreneur frames the development of the NMC on a spatial scale and on a national, rather than a local or regional, level. The quote shows that there is a chance that the entrepreneurs will establish the NMC in the Netherlands, but that there are also other possibilities. It also shows a time scale frame: the entrepreneur refers to the past and is of the opinion that Dutch society is about to decide about the future of intensive agriculture, and the future of food production. Either she accepts the development of NMCs or she decides intensive animal production in NMCs is unacceptable. By putting it this way, the entrepreneur states that it is not up to them as entrepreneurs to decide. He makes it seem as if he does not really care whether and where the NMC will be established in the Netherlands; if not here, then he will go somewhere else. Stating it this way, the entrepreneur gives the creation of the NMC an importance that goes beyond the ADA, municipality, or province: he puts the development on the national level of the administrative scale.

In line with this reasoning, the entrepreneur frames the NMC as a very sustainable concept for future intensive agriculture, an example for the rest of the world that exceeds personal, local, or national interests. He deploys two connected dominant agricultural scale frames. Firstly, he uses a sustainability frame that is comparable to the frame deployed by the alderman.

Looking at poultry farming, which happens to be the sector in which I have grown up, for which we have developed a concept without animal transport, a total reduction of transport, 
in the course of which you're on the road as little as possible, in the course of which you thus totally aren't on the road with animals. And that you've the most efficient use of expensive raw materials and in the course of which you also reuse all your remains [...]. That's, according to me, the most sustainable way of production. We cooperate with other companies, for example pig- and energy-production companies. I think it's an example... that the importance goes beyond my personal interest and also beyond the interest of intensive animal production.

However, whereas the alderman focused his sustainability argument on agriculture in general, emphasizing the advantages of concentration of intensive agriculture, the sustainability frame of the entrepreneur focuses on the innovativeness of the NMC, which makes it a sustainable company or concept.

The last part of the quote shows the second dominant scale frame: the entrepreneur sees the NMC as an example of sustainable intensive animal production of interest to the whole world. The entrepreneur is of the opinion that co-operation in the rest of the world can learn from the experience of the NMC. By constructing the argument that "the importance goes beyond my personal interest and also beyond the interest of intensive animal production", the entrepreneur indirectly refers to the opponents who say that the entrepreneurs pursue only personal economic incentives and to the shortsightedness/unawareness of many people who do not see this importance:

Many people don't see the larger importance of the development we're putting into action.

This is also shown in other parts of the interview where he states:

We want to create an appealing project there, which can serve as a model for the world. This isn't only about us

and where he talks about "the larger plan". These statements also show that for the entrepreneur the concept is just as important as the concrete firm, and therefore it does not matter where the company will be established as long as it is established. Following from this, the preferred location of the NMC (for now) just happens to be in this ADA. This ADA is an interesting location for several reasons (e.g. access to highways, visibility from the highway, opportunities for expansion, innovative agricultural environment), but could have been somewhere else. For example, the entrepreneur currently is also working on a project in India. The entrepreneur has a comparable reasoning for the size of the NMC: "the size is solely determined because we'll build the smallest abattoir that can cost-effectively slaughter chickens." And "the size of the company purely has to do with the concept: no animal transport." (No animal transport means producing from egg to meat and consequently a minimal number of chickens for cost-effective slaughtering.)

Regarding the effects of the NMC on the spatial scale, village level, the entrepreneur is convinced that "nobody in [the village] will even notice" that the farm is there. The direct neighbors will have some more inconvenience, because there will be more traffic and "a little odor every now and then, but not more than presently, since there are already large firms at present." So the entrepreneur makes a distinction between the neighbors who will have some more inconvenience, and the village 3 kilometers away, which will hardly notice the NMC. To underpin this statement, the entrepreneur constructs the argument that the $\mathrm{NMC}$ will be at a greater distance from the village, from the people, from nature than their four farms are now. At their current location, there live " 74 families 
within a radius of 500 meters. And if we build the NMC, then we will have 14 families in a radius of 1,000 meters, and in a radius of 500 meters only 4." So in fact he is of the opinion that the citizens in the village should not be worried, as he explains:

my neighbors never complain. Those are the people who would be so terribly burdened. Who in fact should have died a long time ago, but it's full of small children and they're all healthy.

Thus the entrepreneur is of the opinion that they will improve the situation on a larger spatial level (regional) and will only cause slightly more inconvenience on the neighborhood level. (The other developments around the village, which worry the founder of the action group, form no part of the story of the entrepreneur.)

The entrepreneur is aware of the worries of the citizens in the village. He repeatedly states that he feels really sorry, but they do not have reason to be worried, and it makes him sad how these people are frightened by the media and the action group.

It's a disaster for those people in the village, I think. Mainly that certain actors so enormously cleverly know how to play the game by driving that community apart, because somewhere a chicken farm will be established 3 kilometers outside the village center.

No, the local people, that's something else, those people are sincerely frightened. Those people are simply scared. I find it very terrible that they're scared. It's in fact not acceptable at all. Those people, well, they have images in their minds, and those images came there and I say they're planted there. That has much to do with communication and media.

The fact that he repeats this argument several times shows that the entrepreneur feels really sorry for the citizens. It also shows that he is convinced that the NMC will not cause much inconvenience, except very locally, and that he is frustrated with the fact that it is very difficult to communicate the positive message. 


\section{APPENDIX 5}

\section{Analysis of municipal council meetings}

In the following, the analyses of four important moments in the municipal decision-making process are summarized.

During the municipal council meeting of 14 November, 2006, the NMC initiative is discussed for the first time. In this first meeting the different speakers use different scales and levels to discuss the NMC. The deployed scale frames are comparable to the scale frames deployed by the key actors in the interviews. Two citizens frame the NMC as unsustainable both on the global level, referring to the cutting of the rainforest for soy in Brazil, and their living environment on the local level. We can analyze these frames as spatial scale frames. They frame the NMC as a "pork factory, an industry, which will destroy their environment." This we refer to as an agricultural scale frame. The council addresses one of the scale frames of the citizens (the NMC as industry; an agricultural scale frame). The alderman only acknowledges that the $\mathrm{NMC}$ will have a large spatial impact in a certain area (spatial scale frame). So although it seems that the different actors are discussing the same topic, they use different arguments presented in different scale frames, and they do not explicate these. We see the Socialists address the blending of the discussion about the NMC and the development of the ADA. The alderman does not respond to this. Since the purpose of this meeting is only to debate the NMC, there is no conclusion about the issue.

The criteria for the area vision for the ADA were up for discussion on the agenda of the municipal council meeting of 4 September, 2007. The area vision is seen as a first step in the execution of the reconstruction plan. Since intensive agriculture is traditionally an important economic sector in the municipality, the municipal board wants to lay down conditions for the ADA, "providing for innovative growth of the sector in a sustainable way and offering continuity". Looking at this meeting, we see that the action group emphasizes the accumulation of developments surrounding their village (a spatial scale frame). The council on the other hand is only discussing the ADA (agricultural scale frames), and the alderman explains that he will balance the different functions of the countryside (a spatial scale frame). With regard to the farms in the ADA, the action group highlights the negative aspects of large-scale farms on different scales and levels, the council wants to set all kinds of maxima (agricultural scale frames), and the alderman will limit emissions but at the same time allow for growth, using spatial and administrative scale frames. Here we see scale frame mismatches: different actors, although discussing the same topic but using different scale frames, talk at cross purposes. Also in this meeting different actors deploy different scale frames, which are related to the scale frames as deployed in the interviews: e.g. the "sustainability on a higher level scale frame", the "local accumulation scale frame", the "unsustainability on the global level scale frame".

After the discussion about the criteria, the vision document itself is under discussion during a factfinding council meeting of 11 December, 2007. In this council meeting, the arguments articulated by the citizens and representatives are hardly addressed in the political debate. The citizens are discussing the NMC, whereas the political debate is about the area vision for the ADA: a scale frame mismatch between the agricultural and the spatial scale. Furthermore, the different parties acknowledge that the discussion about the NMC interferes with the ("objective") decision-making process on the area vision, but no suggestions are made to separate the two debates. The alderman hardly reacts in this debate, since it is only a fact-finding discussion. And since the alderman does 
not react and the purpose of the meeting is only to exchange views, there is no need to come to a shared conclusion and the item is left open-ended. In the meeting, the different actors deploy scale frames that are similar to the scale frames that they deployed in earlier meetings. The repeated use of certain typical scale frames shows who is engaging with whom and which actors share the same opinion.

During the municipal council meeting of 12 February, 2008, the municipal council approves the area vision as presented by the board by 11 votes to 10 , under loud protests from local, regional, and national activists. The representatives of the different interest groups, just like in the meeting of 11 December, mainly articulate their worries about the NMC using agricultural scale frames. In this meeting also, the arguments expressed by the citizens and representatives are hardly addressed in the political debate. The citizens discuss the NMC, whereas the debate is about the area vision for the ADA. Again we see the mismatch between the agricultural and spatial scale. The different parties mainly discuss the maximum sizes defined in the area vision and suggest amendments. The alderman, speaking on behalf of the board, advises the rejection of almost all suggestions and amendments. He rejects all the arguments to fix maximum sizes (agricultural scale frames) with his "future-proof time scale frame" and shifts the responsibility to the national level (administrative scale frame), stating that market processes are not local government duties. And the area vision is approved without hardly any amendments. In this meeting also, the different actors deploy scale frames that are similar to the scale frames deployed by the key actors in our interviews. 